\title{
BUDGETING INFORMATION SYSTEM DESIGN IN iFRAMES: CASE STUDY ON HEALTH SECTOR BLUD
}

\author{
Budiman Linggo Santoso $^{1^{*}}$ and Machmudin Eka Prasetya ${ }^{2}$ \\ ${ }^{1,2}$ Universitas Indonesia, Indonesia
}

\begin{abstract}
At the moment, budgeting processes carried out in Regional Public Service Agency in health sector in DKI Jakarta had been done manually so changes between corrective Work Plan and Budget (RKA)s and updated RKA cannot be seen directly. It causes ineffectiveness and bad transparency in the budget preparation process as unconfirmed RKAs are not well documented. The purpose of this study is to create a design of integrated accounting information system between budgeting information system as a part of Integrated Financial Reporting and Management Information System (iFRAMES). Transparency Theory is used to analyze the needs of budgeting transparency in government organization. The method used in budgeting system design is Framework for the Application of Systems Thinking (FAST) as the method in planning system design and the study approach used is a case study with triangulation method with qualitative data in the form of data from interview and quantitative data in the form of document review. The unit of analysis examined in this study is multipleembedded units, between DKI Jakarta Health Office and BLUD. This study resulted in an integrated planning system design for BLUD to support planning activities so planning activities could be carried out with high transparency and efficiency.

Keywords: Accounting Information System, BLUD, Budgeting System, FAST, Puskesmas, RKA, Theory of Transparency.
\end{abstract}

\section{INTRODUCTION}

At the moment, the accounting cycle of the DKI Jakarta Regional Public Service Agency (BLUD) that can be in the form of Community Health Center (Puskesmas) or Disctict Public Hospital (RSUK) field still does not use an integrated application between the budget planning information system, accounting information system, and asset \& inventory information system. Especially in budgeting, data process is still done manually using spreadsheet application and word processor application. This causes the budgeting process takes longer than necessary. Based on the initial interview with one of the Head of the Administration in one of the DKI Jakarta BLUD, budgeting manual process makes the job time-consuming. The use of spreadsheet application and word processor application makes the difference between Work Plan and Budget (RKA) tend to not well-documented. Also, the difference in RKA's items cannot be seen if a review is going to be held to revise older RKA to make more update RKA because there are no clear historical records related to changes in RKA submissions. This also causes a lack of transparency in the budgeting plan because with the absence of changes history of in RKA, at what step and by whom the RKA submission corrections are made will be unknown. The argument is strengthened by audit report by Indonesia Supreme Audit Institution (BPK) (2016) where one of the BLUD in the DKI Jakarta found that there were expenditures of more than 9 billion rupiahs. There was no Fund Disbursement Order (SP2D) related to those expenditures, and they are also no information regarding those expenditures in the BLUD RKA.

Integrated Financial Reporting and Management Information System (iFRAMES) is a system which is consist of budgeting information systems, accounting information systems, and asset \& inventory systems intended for BLUDs. The three systems will have data that are interrelated with one another so that it can facilitate work, be more efficient, and improve the quality of work. In this study, the focus is on the budget planning information system. Reports produced by the budget planning

* Corresponding author. Email address : blinggos@gmail.com 
system will be used by the accounting information system as a guideline for the use of BLUD funds in the following year. An integrated system will save the footprint of data that already existed in the past and will easily access those data and utilized the data because the data is stored in the same system. As the system contained those data in the same place, the data can be processed into the desired output, such as data to be used in the budgeting system and to be used in the accounting information system. Other advantages that can be obtained are time saved and increased transparency in budgeting report preparation because the budgeting is a sustainable process so that if the required data is already available in the same system, then the time to revise the budgeting plan will be significantly reduced. Transparency of the revised plan the budget will be better because changes from one revision to another can be seen where, when, and by whom the changes were submitted. One of the basic thing that is often overlooked in producing accounting reports is input errors so that with the existence of a system, the possibility of input errors can also be reduced by the use of accounting applications (Fardon, 2013).

Integrated Financial Reporting and Management Information System (iFRAMES) is a combination of systems that consist of Budgeting, Monitoring and Evaluation Information System (BORDERS), Accounting and Reporting Information System (ARISE), Asset and Inventory Information System (ASSIST), and Procurement Information System. BORDERS is an information system focused on budgeting planning where other systems are ARISE that will be used when the entity is about to conduct accounting reporting. The others are ASSIST, that will be used by entities to record the reception of new assets, written-off assets that have been damaged or have been lost, and reclassifying assets received from other entities and Procurement Information System is a system used when the entity about to spend the budget in order to carry out its operations. The four systems are integrated to be used by BLUD entities. The four systems will have data that is interrelated with each other so that it can facilitate work, increase efficiency, and improve the quality of work.

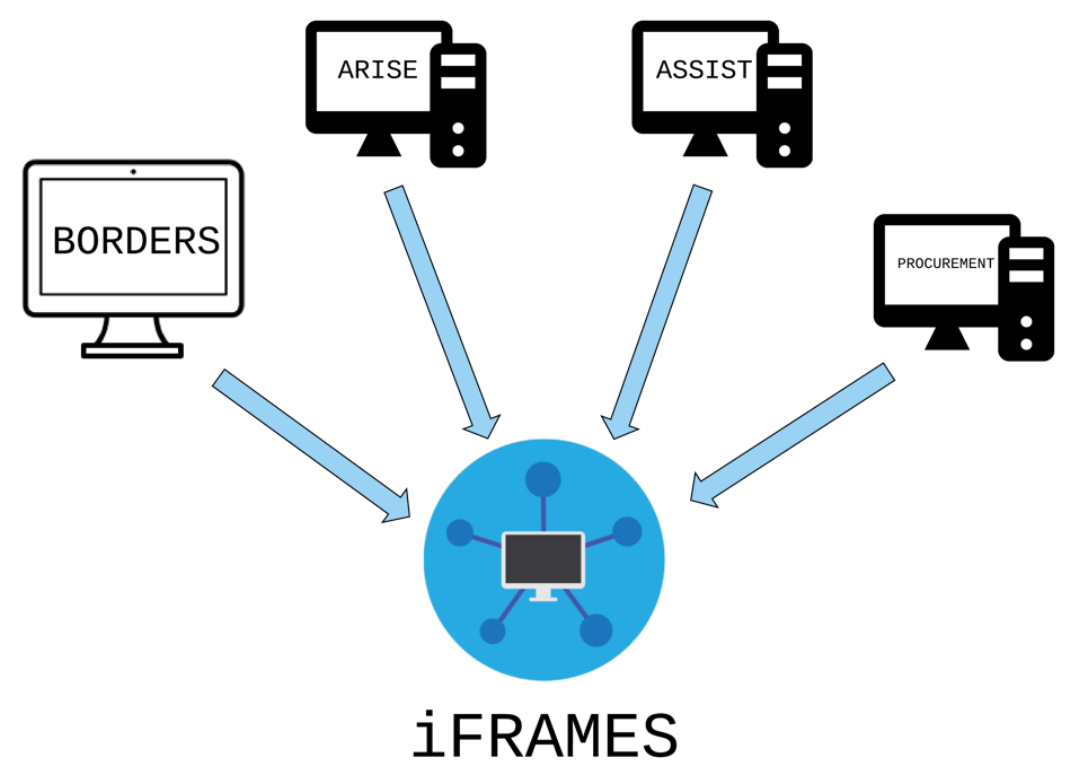

Figure 1 iFRAMES Components

The main objective of this study is to make a design of budget planning information system which will put together with other information systems in iFRAMES which consist of accounting information system and assets and inventory information system. Budgeting information system design is expected to simplify the work of users, saves more time, reduce the possibility of errors, and increase the transparency RKA generated by the system. In practice, after the RKA is completed 
and ready to be used, it will act as guidelines for BLUD to carry out its operations. At the end of an accounting period, RKA can be used as a reference to produce a budget realization report for the period (LRA) so that the LRA can be used as a tool for evaluating the financial performance of the BLUD in the period.

\section{LITERATURE STUDY}

\subsection{Theory of Transparency}

Based on research by Heald in Etzioni (2010), transparency defined in general as a principle that gives the public access to information about the operations and structure of an entity. Transparency based on transpararency-initiative.org in Shrivastava (2015) is easily seen as a whole. Regarding politics, transparency is a phenomenon of the escalation of public trust in the government and vice versa, the increase of government trust in the public. Transparency is a process which is needed to regulate a country. Transparency as known by people, in general, is a way to see the work of the government.

Rapid progress in internet use significantly increases people's access to information about public policies and local government policies. People can access minutes of government meetings, regional budgets, and people can contact officials directly responsible for various community services (Otenyo \& Lind, 2006). System design created in this study uses internet network as one of the important parts of the process both for data input, control functions and RKA publications that can be accessed by the public.

\subsection{Previous Studies}

Setyawan (2014) conducted a study about the analysis and design of information systems in budget planning and activity control in multi-level schools. The study resulted in a web-based budget planning system and multi-level school activity control design from the determination of the budget allocation set to fund organizational expenditure up to the budget realization report as a management control function.

In addition to the above research, there is also study conducted by Hananto et al. (2014) which discusses the design of budgeting systems that concentrate on performance-based budgeting systems that have not been effective at Sebelas Maret University (UNS) Surakarta. The research produced a system design so that the strategic plan, unit cost calculation, Key Performance Indicators, budgets, and assessments of budgeted activities can be integrated into one system to increase the effectiveness of its budgeting system.

\subsection{BLUD and Work Plan \& Budget (RKA)}

BLUD based on the information described in the Minister of Home Affairs Regulation (2007), BLUD are Regional Work Unit (SKPD) in the local government which aims to provide public in the form of providing goods and services not oriented in profit. The difference between Public Service Agency (BLU) and BLUD is to whom BLU and BLUD are responsible to. If it is directly responsible to the ministry, then the agency is called Public Service Agency (BLU). But if the agency is directly responsible to the local government, then the agency can be categorized as the BLUD.

According to Governor's Regulation (2012), RKA is a document containing the projection of income, expense, cash flow, quantity and quality of goods or services to be produced. RKA is used as a basis for budget planning by the BLUD. RKA is also useful when LRA evaluation is about to be in the period to come 


\subsection{System Development}

The system development process is a series of activities, methods, practices, final results, and tools used by stakeholders to develop and maintain information systems and software (Whitten \& Bentley, 2007). Most systems development processes apply a problem-solving approach where this approach typically includes general steps to solve. They are: recognize the problem, analyse and understand the problem, identify solutions, steps and expectations, identify alternative solutions and choose the best action, design the chosen solution, implement the chosen solution, and evaluate the results (If the problem is not resolved, go back to the first or second step).

There are four phases to simplify the problem-solving approach on system development projects, which are system initiation, system analysis, system design, and system implementation. The table below shows the correlation between general problem-solving steps and the system development process.

Table 1 Simplified System Development Process relationship with ProblemSolving Approach

\begin{tabular}{|l|l|}
\hline \multicolumn{1}{|c|}{$\begin{array}{c}\text { Simplified System Development } \\
\text { Process }\end{array}$} & \multicolumn{2}{|c|}{ General Problem-Solving Steps } \\
\hline System Initiation & 1. $\begin{array}{l}\text { Identify the problem and plan for a } \\
\text { solution. }\end{array}$ \\
\hline System Analysis & $\begin{array}{l}\text { 2. Analyze and understand the problem } \\
\text { 3. Identify solution requirements and } \\
\text { expectations }\end{array}$ \\
\hline System Design & 4. $\begin{array}{l}\text { Identify alternative solutions and choose } \\
\text { the best actions }\end{array}$ \\
\hline System Implementation & 5. Design the solution \\
& $\begin{array}{l}\text { 6mplement the solution } \\
\text { 7. } \begin{array}{l}\text { Evaluate results (If the problem still } \\
\text { unsolved, go back to step 1 or step 2) }\end{array}\end{array}$ \\
\hline
\end{tabular}

Source: Whitten and Bentley (2007)

\subsection{FAST (Framework for the Application of Systems Thinking) Methodology}

FAST (Framework for Application of Systems Thinking) Methodology is a hypothetical methodology used by Whitten and Bentley (2007) to demonstrate a representation of the system development process. The FAST methodology describes the simplified system development process explained above in more detail. The FAST methodology has eight phases, including:

1. Scope Definition

This phase is used to answer whether a problem needs to be resolved and if the problem needs to be settled then a plan must be arranged to resolve the problem. James Wetherbe in Whitten and Bentley (2007) developed a framework for classifying system problem, opportunities, and directives. It is called PIECES which consist of six categories that when put together will form the word 'PIECES', they are: P for Performance; I for Information \& data; E for Economics, control costs, or increase profits; C for control or security; E for efficiency of people and processes; $\mathrm{S}$ for service to customers, suppliers, partners, employees, and many others.

2. Problem Analysis

This phase discusses the existing system and analyses to understand the underlying problems of a project and to answer whether the benefits resulting from solving the problem are greater than the costs incurred.

3. Requirement Analysis 
This phase discusses what needs to be met by system makers so that system makers can develop the system according to what the system user wants.

4. Logical Design

The system model aims to change business requirements into a description of a system that represents reality or desired reality to facilitate communication between system users, system analysts, system designers, and system makers so that it can also be used to validate completeness and consistency with business requirements.

5. Decision Analysis

The purpose of this phase is to identify the choice of solutions, analyze the possibility of implementing the solution, and recommend a solution to be designed.

6. Physical Design and Integration

Physical design is the opposite of logical design where logical design relates to business requirements, while physical design represents specific technical solutions.

7. Construction and Testing

The purpose of this phase is to build and test a system that can meet the business requirements and physical design specifications and to implement a new system with existing systems.

8. Installation and Delivery

This phase is the phase where the functional system is implemented and this phase also where system users are trained to use a new system, convert existing data to a new database, and do the latest system testing.

9. System Operation and Maintenance

After the system operates, the system requires support services as long as the system is still functioning and still in its productive age. Other forms of service can be changing the system so that it can adapt when there are changes in business problems and technical problems or also because of changes in business needs and technological needs.

\subsection{Process Modelling}

Data flow diagram or commonly abbreviated as DFD is one of the techniques used in process modeling. DFD itself is a graphical description of data flow within an organization, which includes data/destination sources, data flow, transformation processes, data storage (Romney \& Steinbart, 2015). The symbols used in DFD are as follows: 
AFEBI Accounting Review (AAR)

Vol.03 No.02, December 2018

Table 2 Data Flow Diagram Symbols, Name and Description

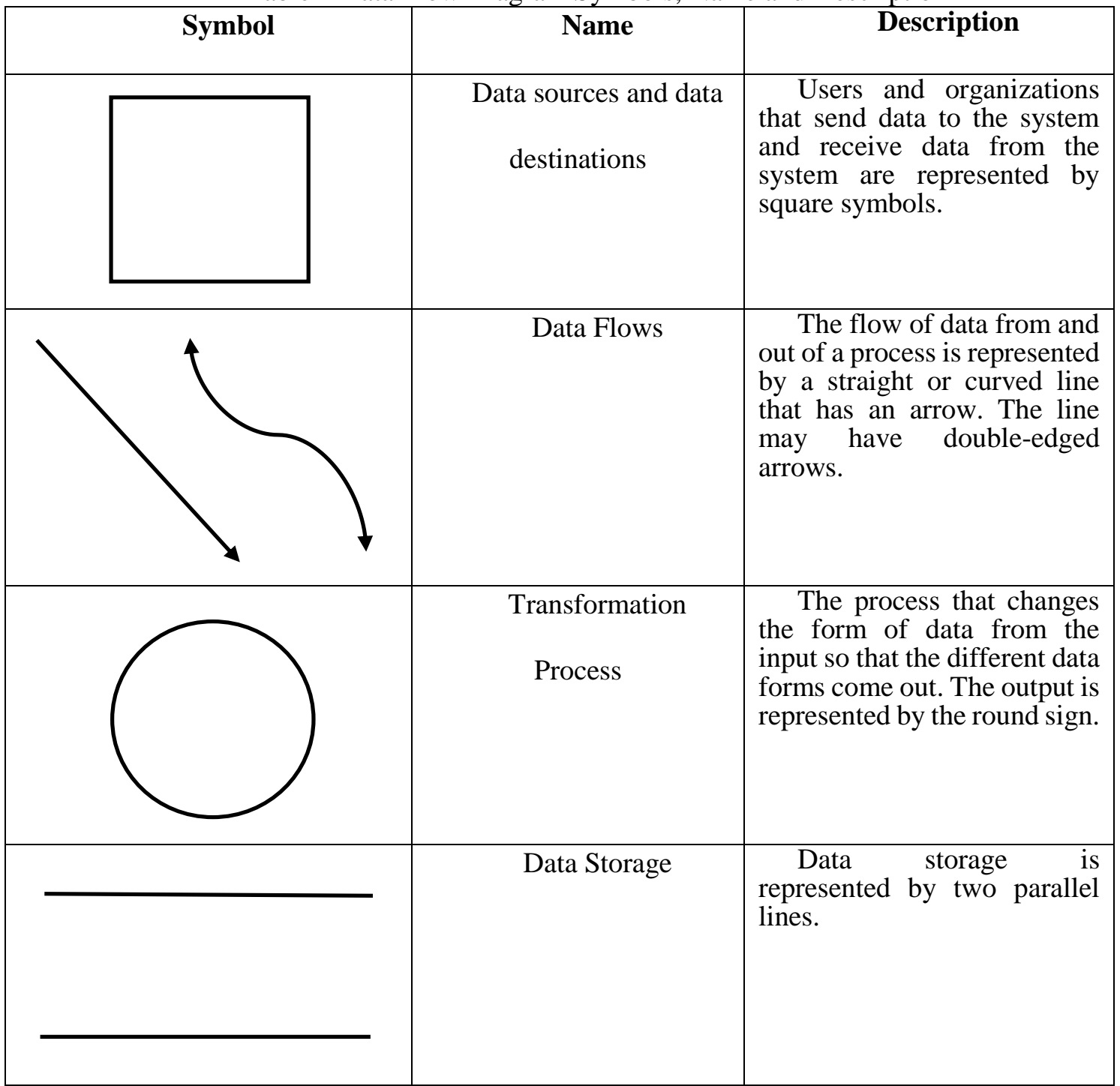

Source: (Romney dan Steinbart, 2015).

DFD is divided into several levels to provide a high level of system detail. The highest level of DFD is also called the context diagram because this diagram presents the user with a concise display of a system. One level under the context diagram is called DFD Level 1 which is the breakdown of the context diagram system and one level below DFD Level 1 is called DFD Level 2. DFD Level 2 is the breakdown of the transformation process existed in DFD Level 1. System breakdown on DFD can be done as far as needed by a system designer.

\section{RESEARCH METHODOLOGY}

\subsection{Research Methods}

This study is a case study which is a qualitative study to answer the question that cannot be answered by quantitative research which is how and why. This research is made to answer how the design of budgeting information system. Therefore a case study is a right tool for answering the question.

The research using mixed methods research model. It is a research that involves a mixture of qualitative methods and quantitative methods (Johnson et al., 2007) as this research will mix data from qualitative data in the form of an interview and quantitative data in the form of document review. This research also 
uses concurrent mixed analysis in the data collection process as data are collected simultaneously. An interview is conducted to obtain information in system designing, and document review data are for supporting interview data.

Research that uses mixed methods model tends to put qualitative and quantitative equal in weight (equal status) or to lean heavier on one side than on the other (dominant status). Dominant status is the adapted model use by this paper where qualitative approach will be more emphasized than the quantitative approach. Data from the interview are primary data wherein data from document review are used to support data from the interview.

\subsection{Unit Analysis}

Based on Skogerbø (2011), there are several kinds of unit analysis; they are a single unit, multiple unit, and multiple-embedded unit. This research uses multipleembedded units as there is a vertical relationship between Health Office of DKI Jakarta (Dinas Kesehatan DKI Jakarta), Puskesmas, and RSUK because these three entities are entities that are included as units analysis in this research.

\subsection{Data Collection}

Data collected are coming from interview and document review. Interview conducted by interviewing budgeting unit of Puskesmas and budgeting unit of RSUK. Author also interviewed a Financial Department Health Office of DKI Jakarta staff to find out the relationship between the community health centre, RSUK, and the Health Office of DKI Jakarta whereas document review is done to support data obtained from the interview.

\subsection{Data Analysis}

This research uses the FAST methodology to generate output in the form of budgeting information system design. The first step is Scope Definition where the problems are listed. Afterward, the next step is called Problem Analysis where the impact of the problem is described. The third step is where the solution to the problem is stated which called Requirement Analysis. The last step of the FAST methodology used in this research is Logical Design where design made to ease communication between system designer, system user, and system maker to make the system to solve the problems.

\section{RESULTS}

\subsection{Scope Definition and Problem Analysis}

FAST methodology is used to identify problems, the impacts, solution, and to make a logical design of a system to solve problems of the prospective system users. Based on data obtained from interviews with respondents, author interpret the data from those interviews which contained the problems faced by respondents in order to see the possible impact from the problems and to seek possible solutions and make a logical design of a system to overcome those problems. The first step to be taken is to classify problems faced by respondents which triggers the intention to make a system design. This step is called Scope Definition, where problems are listed and classified based on PIECES categories. The second step is to list the possible impact caused by those problems. The next step is called Problem Analysis where solutionS for the problems is going to be sought. Table 3 listed the Problems and Impacts classification using PIECES analysis based on data from interviews: 
AFEBI Accounting Review (AAR)

Vol.03 No.02, December 2018

Table 3 List of Problems and Impacts

\begin{tabular}{|c|c|c|}
\hline \multirow{3}{*}{ Performance } & $\begin{array}{c}\text { Problems } \\
\end{array}$ & Impact \\
\hline & $\begin{array}{l}\text { Preparation of is still done } \\
\text { manually using the } \\
\text { spreadsheet application }\end{array}$ & $\begin{array}{l}\text { RKA preparation is quite a } \\
\text { time consuming }\end{array}$ \\
\hline & $\begin{array}{l}\text { There is no mechanism that } \\
\text { will remind users when there } \\
\text { is a low budget absorption } \\
\text { rate }\end{array}$ & $\begin{array}{l}\text { There is a monitoring } \\
\text { function to monitor budget } \\
\text { utilization which should be } \\
\text { optimized to improve BLUD } \\
\text { performance }\end{array}$ \\
\hline Information and Data & $\begin{array}{l}\text { Changes in RKA data are } \\
\text { not well documented at each } \\
\text { evaluation step }\end{array}$ & $\begin{array}{l}\text { Difficulty in tracking } \\
\text { changes in RKA data } \\
\text { because there are several } \\
\text { versions of RKA submission }\end{array}$ \\
\hline $\begin{array}{ll}\text { Economics, } & \text { Control } \\
\text { Costs or Increase Profits }\end{array}$ & $\begin{array}{l}\text { RKA evaluation is done } \\
\text { manually where District } \\
\text { Planning and Budget Staff } \\
\text { have to come to the Health } \\
\text { Office of the Province to do } \\
\text { the evaluation }\end{array}$ & $\begin{array}{l}\text { There are expenses that } \\
\text { can be saved related to } \\
\text { transportation costs when an } \\
\text { evaluation is going to be } \\
\text { held }\end{array}$ \\
\hline Control/Security & $\begin{array}{l}\text { The unavailability of a } \\
\text { digital approval mechanism } \\
\text { that meets adequate security } \\
\text { standards }\end{array}$ & $\begin{array}{l}\text { RKA data is vulnerable to } \\
\text { being illegally accessed and } \\
\text { altered by unauthorized } \\
\text { parties }\end{array}$ \\
\hline $\begin{array}{l}\text { Efficiency of people and } \\
\text { processes }\end{array}$ & $\begin{array}{l}\text { There is no integrated } \\
\text { system that combined } \\
\text { budgeting information system } \\
\text { with accounting information } \\
\text { systems }\end{array}$ & $\begin{array}{l}\text { The process of preparing } \\
\text { budget realization reports is } \\
\text { still done manually by } \\
\text { requesting data from the } \\
\text { Finance Department }\end{array}$ \\
\hline $\begin{array}{l}\text { Service to customers, } \\
\text { suppliers, partners, } \\
\text { employees, and so on. }\end{array}$ & $\begin{array}{l}\text { There is no publication of } \\
\text { the on BLUD budget that can } \\
\text { be accessed easily by the } \\
\text { public }\end{array}$ & $\begin{array}{l}\text { This aspect has not } \\
\text { complied with Governor's } \\
\text { Regulation of DKI Jakarta } \\
\text { Number } 175 \text { the Year of } \\
2016 \text { which requires BLUD } \\
\text { to provide information on } \\
\text { programs and activities } \\
\text { budget sourced from BLUD } \\
\text { funds }\end{array}$ \\
\hline
\end{tabular}

\subsection{Requirements Analysis}

This step is the third step in FAST methodology where the solution to the problem presented above is:

- A system that reduces or eliminates manual processes

- A system that has monitoring and evaluation features for the budget realization

- A system that has a file log feature so that the system can document the history of RKA changes

- System features that able to facilitate RKA evaluation process without having to come to the evaluation actual place

- Digital signature features to overcome the integrity of the RKA data

- A budgeting information system that is integrated with accounting information systems

- A budgeting system feature that can provide budget information that can be easily accessed by the public 


\subsection{Budgeting, Monitoring, and Evaluation Information System (BORDERS)} Logical Design

Figure 2 is the logical design of BORDERS in the form of a context diagram which is a process model that is used to describe the interaction between external entities and the system. The diagram made based on data from interviews and based on data from Regional Secretary Instructions (2016) which is changed into the form of a diagram to facilitate communication between system designer, system maker, and system user so that the required features are available in the system that is going to be built and to facilitate communication between those parties.

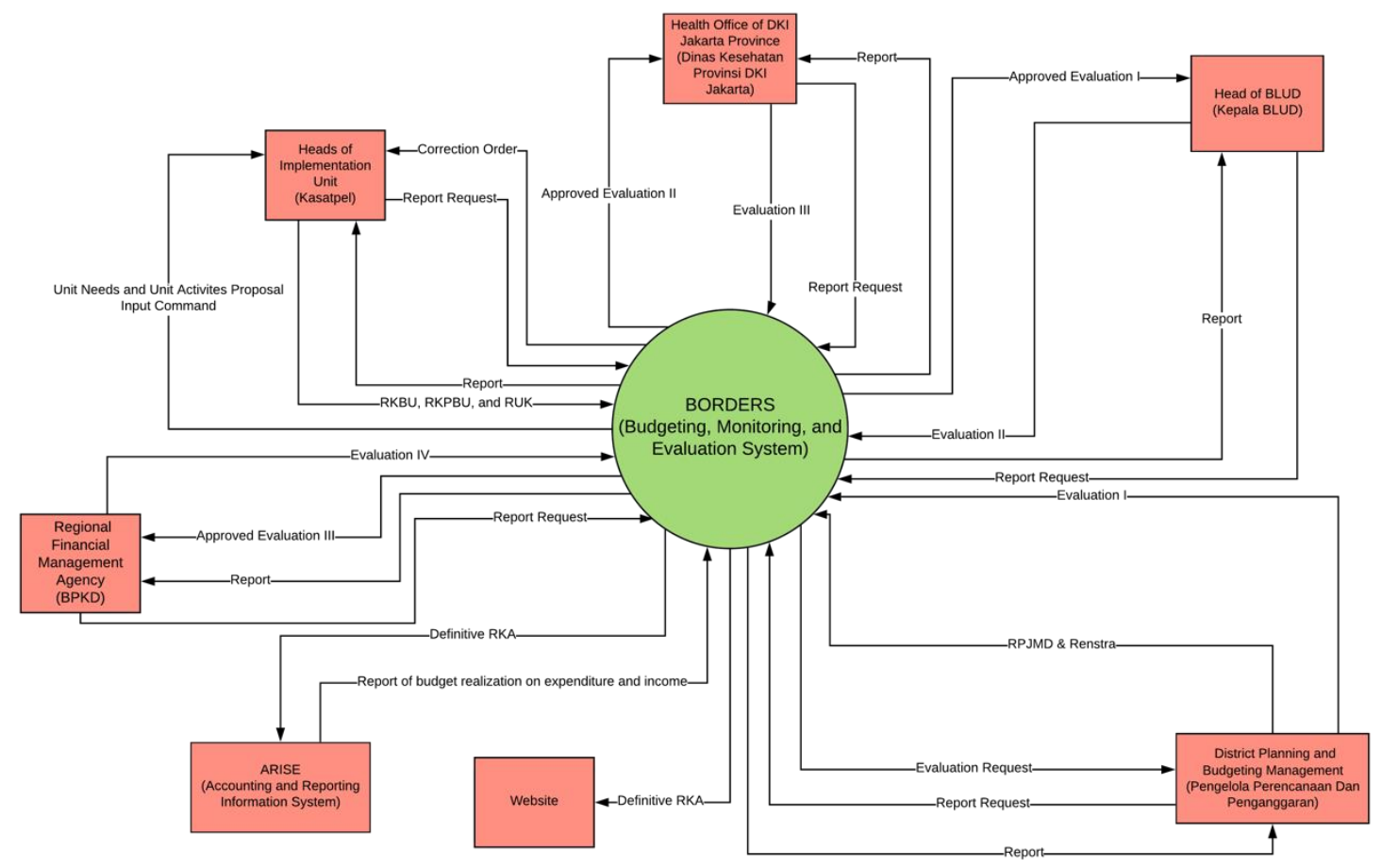

Figure 2 Context Diagram of BORDERS

\section{DISCUSSION}

The beginning of data flow from the data flow diagram at district level above is the input of the Regional Medium Term Development Plan (RPJMD) and Strategic Plan (Renstra) by District Planning and Budgeting Managers into the system and give orders to Heads of Implementing Unit to input their unit needs and their unit activities plan in the next year to the budgeting information system. Heads of Implementing Unit consists of Head Unit of Community Health, Head Unit of Individual Health, and Head Unit of Implementation Unit in subdistrict level. These Head Units send their Unit Goods Need Plan (RKBU), Unit Assets Maintenance Plan (RKPBU), and Unit Proposed Activity Plan (RUK) into BORDERS (Budgeting, Monitoring, and Evaluation Information System).

BORDERS then send the proposals to the District Planning and Budgeting Division for review. If there are corrective actions are needed, District Planning and Budgeting Division will order the system to send a corrective order to Heads of Implementing Unit to fix their proposals. After the proposals have been fixed by the responsible parties, they put back corrected proposals into the system and the system will notify District Planning and Budgeting Division to review Heads of Implementing Unit proposals.

After the proposals have been approved by the District Planning and Budgeting Division, the next step is to ask for District Head of BLUD approval. The District Head of BLUD receives notifications from the system to evaluate units needs and units 
activities that have been approved by District Planning and Budgeting Division. If there is a correction that needs to be corrected, the Head of BLUD will make corrective orders to the Heads of Implementing Unit to fix their units needs and units activities proposals. Then the evaluation process is carried out again to the District Planning and Budgeting Division and District Head BLUD after corrections have been made by Heads of Implementation Unit.

If approval has been done by the Head of BLUD, next process will be the Health Office of the DKI Jakarta Province. The same process is carried out again where the Health Office of the Province will evaluate the proposals of Heads of Implementation Unit. If there are correction requested by the Health Office, system will give a correction order to Heads of Implementation Unit to make corrections after the Health Office notifies what things need to be corrected and the same process will be carried out once again where corrected the proposals will need to be approved by District Planning and Budgeting Division, Head of BLUD and Health Office of the Province. Positive review by the Health Office will continue the proposals to Regional Financial Management Agency of BLUD.

The final evaluation is carried out by Regional Financial Management Agency of BLUD where when proposals have been approved the system can produce definitive RBA which can be used by the accounting information system for the basis BLUD budget use. But when Regional Financial Management Agency of BLUD asks for corrections to the Heads of Implementation Unit, system will give a correction order to Heads of Implementation Unit to correct their proposals and review process will be carried out from District Planning and Budgeting Division until the approval of Regional Financial Management Agency of BLUD have been made then BLUD budget can be used.

This research found that BLUD still does not have budgeting information system that can ease the work, cut time, increase transparency of the data, keep the integration of the data, and lower costs of the budgeting process. This argument is aligned with research done by Pardamean \& Setyodewi (2014), which also found that the budget system eliminates difficulties in data access, data errors, inefficiency, and reduce the time needed. The budgeting information system design in Figure 2 is a part of a larger grand design called iFRAMES. In iFRAMES itself, besides the budget information system, there are accounting information system and asset and inventory system. These three systems work together to create an integrated information system to be used by BLUDs to support their activities so to make work easier, more effective and transparent because the gaps for fraud will become as supervision of the RKA will become tighter.

The budgeting information system is a web-based information system. The form of the web-based system is indicated from when RKA is ready to be used by a BLUD, RKA will be available on the website for public so that supervision of budget by public can be done as public can supervise the use of the budget. This effort is done to comply with the Transparency Theory used in this research.

Previously there had never been researches about budgeting information system design in BLUD. This fact shows that this research brings uniqueness, authenticity, and new things to information systems that the research is conducted in government-owned bodies. This study can be explored deeper as there is not much similar research on government agencies.

\section{CONCLUSION}

Based on information obtained from the interview, BLUD in health sector does not have a system that can support the work of the BLUD budgeting planning. The absence of a system makes the work harder and takes longer than needed. Also, the results of the work produced are also not as accurate as when the work is supported by a system, has weak data integration, susceptible to errors and inconsistencies. Therefore, iFrames is present to overcome the problem of the absence of a system that 
supports BLUD performance, which in this study focuses on the budget planning system called BORDERS. BORDERS is expected to overcome the problems mentioned above so that the results of the work can be better.

When the system already exists, the resulting work can be better, especially regarding transparency. When associated with the Transparency Theory used in this study, the final result in the form of a definitive Work Plan and Budget (RKA) that can be accessed by the public through the BLUD website is one of the efforts to increase transparency in government bodies. The public can oversee financial management by ensuring that the work program carried out by the BLUD is by the RKA.

This research only focuses on one information system, which is budgeting information system and not a fully-integrated system design. The same researcher or a team of researchers that design a fully-integrated system design will have more knowledge about the system as the researcher or the team is/are the ones that designed it. They will now right away what is the weaknesses that must be improved, advantages of the system, and know where the place in the system failures likely to happen.

Further research for this study can be in the form of an integrated financial reporting and management information system that also included procurement information system along with budgeting information system, accounting information system, and assets \& inventory information system to be used in other government agencies with modification. Because a system that can work in one entity will not always be able to work in another entity properly if there is no change to the system done as the needs of one entity to another can be different. Modifications is a must in order a system can work properly.

\section{References}

BPK, P. P. D. J. (2016). Laporan Hasil Pemeriksaan atas Laporan Keuangan Pemerintah Daerah Provinsi DKI Jakarta-Buku II SPI. DKI Jakarta.

DKI Jakarta, P. Peraturan Gubernur Provinsi DKI Jakarta tentang Pola Pengelolaan Keuangan Badan Layanan Daerah, Pub. L. No. 165 (2012). Indonesia.

Etzioni, A. (2010). Is Transparency the Best Disinfectant? The Journal of Political Philosophy, (Blackwell Publishing Ltd.).

Fardon, M. (2013). Computer Accounting Systems Tutorial (p. 495). Osborne Books Limited. Retrieved from https://books.google.co.id/books?id=AzyQnAEACAAJ

Hananto, S. T., Kurniasih, L., Ramadhan, A. F., \& Juliati. (2014). Desain Sistem Penganggaran Berbasis Kinerja/ Studi kasus UNS. Seminar Nasional Sistem Informasi Indonesia.

Menteri Dalam Negeri, I. Peraturan Menteri Dalam Negeri Nomor 61 Tahun 2007 tentang Pedoman Teknis Pengelolaan Keuangan Badan Layanan Umum Daerah (2007). Indonesia.

Otenyo, D. E. E., \& Lind, N. S. (2006). Faces and Phases of Transparency Reform in Local Government. International Journal of Public Administration.

Pardamean, B., \& Setyodewi, H. (2014). No TitleInformation System Model of A Work-Plan Budget Pardamean and Setyodewi 2014. Journal of Software, 09(Academy Publisher), 1095-1106.

Romney, M. B., \& Steinbart, P. J. (2015). Accounting information systems (13th ed.). New Jersey: Pearson Education, Inc.

Sekretaris Daerah DKI, J. Instruksi Sekretaris Daerah Provinsi DKI Jakarta 56 Tahun 2016 tentang Penyusunan Dokumen RBA SKPD/UKPD BLUD (2016). 
AFEBI Accounting Review (AAR)

Vol.03 No.02, December 2018

Indonesia.

Setyawan, S. H. (2014). Analisis dan Perancangan Sistem Informasi Perencanaan Anggaran dan Pengendalian Aktivitas Sekolah Multi-Jenjang. Seminar Nasional Sistem Informasi Indonesia.

Shrivastava, A. (2015). Theory of Transparency: The Right to Know. University of Petroleum and Energy Studies.

Skogerbø, E. (2011). Perspectives and methods in media research. In Case studies and comparative analysis. Oslo. Retrieved from http://www.uio.no/studier/emner/hf/imk/MEVIT4800/h11/undervisningsmateria le/MEVIT4800 2011_2_250811.ppt.pdf

Whitten, J. L., \& Bentley, L. D. (2007). Systems Analysis \& Design Methods. McGrawHill/Irwin. 